PRACTISING FRENCH CONVERSATION IN FIFTEENTH-CENTURY ENGLAND

Author(s): Rory G. Critten

Source: The Modern Language Review, Vol. 110, No. 4 (October 2015), pp. 927-945

Published by: Modern Humanities Research Association

Stable URL: http://www.jstor.org/stable/10.5699/modelangrevi.110.4.0927

Accessed: 25-09-2015 09:01 UTC

\title{
REFERENCES
}

Linked references are available on JSTOR for this article:

http://www.jstor.org/stable/10.5699/modelangrevi.110.4.0927?seq=1\&cid=pdf-reference\#

references tab contents

You may need to $\log$ in to JSTOR to access the linked references.

Your use of the JSTOR archive indicates your acceptance of the Terms \& Conditions of Use, available at http://www.jstor.org/page/ info/about/policies/terms.jsp

JSTOR is a not-for-profit service that helps scholars, researchers, and students discover, use, and build upon a wide range of content in a trusted digital archive. We use information technology and tools to increase productivity and facilitate new forms of scholarship. For more information about JSTOR, please contact support@jstor.org. 


\section{PRACTISING FRENCH CONVERSATION IN FIFTEENTH-CENTURY ENGLAND}

This essay takes as its focus the Manières de langage, a complexly interrelated group of conversation manuals that were written in order to facilitate the instruction of French in late medieval England. ${ }^{1}$ The thirteen surviving texts are located in ten manuscripts, all of which date to the first half of the fifteenth century. Alongside the Manières, these codices often also contain other kinds of French teaching materials, including word lists, verb tables, collections of model letters, and grammar and spelling treatises. The conversation manuals would thus appear to have constituted an important element in late medieval French curricula insofar as they offered students an opportunity to see in action the principally morphological and orthographic rules that constituted the backbone of the language theory explicated in the other teaching texts. ${ }^{2}$ They must also have provided some light relief. As we shall see, the authors of the Manières frequently deploy topical references and comic turns of phrase in ways that seem designed to demonstrate the real-world applications of the matter taught and to maintain students' interest. The most recent editor of the Manières, Andres M. Kristol, deduces that the thirteen extant texts derive from three manuals produced successively in 1396,1399 , and 1415 , and his edition reproduces representative texts of these versions. ${ }^{3}$ My primary goal here will

${ }^{1}$ Citations from the Manières will be by page and line number from Manières de langage (1396, 1399, 1415), ed. by Andres M. Kristol, Anglo-Norman Texts, 53 (London: Anglo-Norman Text Society, 1995). Where reference is made to the numbering of the dialogues within the individual Manières, these numbers are also taken from Kristol's edition. Kristol discusses the manuscripts of the Manières and their dating in his introduction (pp. xvii-l).

2 On the late medieval French curricula, see two important articles by William Rothwell, 'The Teaching of French in Medieval England', $M L R, 63$ (1968), 37-46, and 'The Teaching and Learning of French in Later Medieval England', Zeitschrift für französische Sprache und Literatur, 111 (2001), 1-18. See too the surveys of the manuscript evidence for French teaching in England in Andres Max Kristol, 'L'Enseignement du français en Angleterre $\left(\mathrm{xIII}^{\mathrm{e}}-\mathrm{XV}^{\mathrm{e}}\right)$ : les sources manuscrites', Romania, 111 (1990), 289-330, and the texts and manuscripts listed under the heading 'Grammar and Glosses' in Ruth J. Dean and Maureen B. M. Boulton, Anglo-Norman Literature: A Guide to Texts and Manuscripts, Anglo-Norman Text Society, Occasional Publications Series, 3 (London: Anglo-Norman Text Society, 1999), pp. 157-78. Readers with an interest in the longer durée can consult Douglas A. Kibbee, For to Speke Frenche Trewely: The French Language in England, 1000-160o. Its Status, Description and Instruction, Studies in the History of the Language Sciences, 60 (Amsterdam: Benjamins, 1991). Also still useful in this last regard is Kathleen Lambley, The Teaching and Cultivation of the French Language in England during Tudor and Stuart Times, with an Introductory Chapter on the Preceding Period, Publications of the University of Manchester, 129 (Manchester: Manchester University Press, 1920).

3 In what follows I take over Kristol's practice of referring to the 1396, 1399, and 1415 Manières. At the same time, as Kristol observes, it should be noted that the Manieres were used concurrently and 


\section{Practising French Conversation in Fifteenth-Century England}

be to provide an account of the French taught in these conversation manuals; in particular, I hope to demonstrate their attempts to model current, spoken French. I then go on to examine the milieux in which the Manières were deployed and to offer a reconsideration of the ambitions of the students who used them. Here I focus on the classrooms of the Oxford dictatores, a succession of business teachers who existed on the fringes of the late medieval university and who taught French alongside the other skills needed to perform basic commercial and legal procedures. As well as preparing their students for rudimentary clerical work at home, I contend, the dictatores and their colleagues throughout England also equipped learners with the language proficiency necessary in order to capitalize on the opportunities afforded by the country's Continental possessions, especially Normandy, which fell into English hands during the short reign of Henry V (1413-1422). Examined from this angle, the Manières offer a fresh point of entry into current discussions of the effects of medieval pedagogy on social mobility: I conclude with an account of what the Manières have to offer to studies of this topic.

What, then, did the Manières teach? The functional language practised in these texts varies considerably in its complexity. At the most basic level, they contain numerous dialogues that model the ways in which learners can frame greetings, ask the way and the time, obtain a room in a hostel, and haggle at a market. The 1399 Manière, which is introduced as 'un petit livre pour enseigner les enfantz' (p. 49, 1. 2: 'a little book to teach children'), has a particularly high density of such basic conversations. ${ }^{4}$ Thus towards the beginning of this manual, we find the following brief exchange:

- Sire, Dieu vous doint bon jour.

- Dieu vous doint bon jour et bon estraine. Ou: ... bon santé. Ou: . . bon joie.

- Dame, Dieu vous doint bonnez vespres.

- Sire, vous soiez le bien venu.

- Dieu vous avant, bon amy.

- Dieu vous garde de mal, m'amye.

- Quelle heure est il de jour?

that the distinction between the 1396, 1399, and 1415 texts is not always clear: different versions of the three Manières can accompany each other in the same manuscript, and the texts' scribes seem on occasion to have combined material from more than one textual tradition. Finally, Kristol identifies the survival of fourteen Manières texts in manuscript. I count thirteen of these as conversation manuals; the fourteenth text, in Cambridge, Trinity College MS B 14.39/40 (fols $\left.179^{\mathrm{r}}-180^{\mathrm{v}}\right)$, is a copy of the prose fabliau included in some of the versions of the 1396 Manière (discussed below). See Manières, ed. by Kristol, p. xi.

4 The translations given in this essay are my own. Alongside Kristol's glossary (see Manières, ed. by Kristol, pp. 98-118), I have also consulted the two editions of the Anglo-Norman Dictionary, ed. by William Rothwell and others and hosted at <www.anglo-norman.net> (AND1 and $A N D_{2}$ ), as well as the Dictionnaire du Moyen Français, ed. by Robert Martin and others, hosted at <www.atilf.fr/dmf $>$ $(D M F)$, which provides links to pages scanned from the Dictionnaire de l'ancienne langue française, ed. by Frédéric Godefroy (Paris: Vieweg, 1881-1902) (DAL) and from the Französisches etymologisches Wörterbuch, ed. by Walter von Wartburg and others (Bonn: Klop, 1928-2003) (FEW). 
—Prime. Ou: Tres. Ou: Middy. Ou: Noune.

-Quantez heures est il?

- Entre six et sept.

- Combien decy a Paris?

-Douse liaues ou auques. (p. 53, 1l. 2-14)

- Sir, God give you good day.

— God give you good day and good fortune. Or: . . good health. Or: ... good pleasure.

- Madam, God give you good evening.

- Sir, may you be welcome.

- God help you, good friend.

- God keep you from harm, my friend.

- What time of day is it?

— Prime [early morning]. Or: . . Terce [mid-morning]. Or: . . Midday. Or: . . None [mid-afternoon].

-What time is it in hours?

- Between six and seven.

- How far from here to Paris?

- Twelve leagues or thereabouts.

The first few lines of this dialogue collect a variety of alternative greetings. The speakers then go on to model two ways of asking the time and some appropriate answers before broaching the topic of a journey to Paris; the ten concluding lines of the dialogue that are not cited here discuss the route's trajectory and its occupation by highwaymen. This kind of exchange is the bread and butter of the conversation manuals. Two more such dialogues occur in the 1399 Manière (dialogues 2.2 and 2.3); more or less developed conversations of this type are also included in the Manières of 1396 (dialogues 4.3 and 15) and 1415 (dialogue 3).

Not all the French taught in the 1399 Manière is as polite as that demonstrated in the preceding citation. On the same folio of the manuscript from which Kristol edits this text (Oxford, All Souls MS 182, fol. $323^{\mathrm{v}}$ ) there begins a list of insults that might be drilled individually or practised dramatically as part of a classroom slanging match:

- Mauvaise ribaud, vous mentez.

- Alez, ribaud, vous pendre.

- Ribaud, vous estez digne d'estre perdu.

- Alez decy, senglent filz de putaigne.

- Certez, pailard, vous ne eschiverez jamais.

- Garçon, vous le achetrez.

- Ribaud, vous baserez mon cuel.

- Va, ribaud, le diable vous confonde.

—Pailard, je serrey bien vengé de vous. (p. 54, 11. 26-34)

- You're lying, you evil fucker.

- Go hang yourself, fucker.

- Hell's the only place for you, fucker. 


\section{Practising French Conversation in Fifteenth-Century England}

- Get out of here, you bloody bastard.

- There's no way you're escaping, you scumbag.

- Boy, you'll pay for it.

- Fucker, you can kiss my arse.

- Get out of here, fucker, the devil's going to fuck you up.

- I'll get my own back on you, you scumbag. ${ }^{5}$

The passage is subsequently interrupted by five lines that model the wooing of a damoiselle before picking up again in much the same fashion for a further twenty-four lines (dialogues 3.2 and 3.3).

Nor is the target language studied in the Manières always as straightforward as that modelled in the first example from the 1399 Manière. Alongside conversations that demonstrate the French required in order to console a crying child (dialogue 11), reject a beggar (dialogue 12), or comfort an ill acquaintance (dialogue 20), two of the extant versions of the 1396 Manière contain a comic scene in which a lord wakes up his valet, Janyn, after they have spent a night partying at an inn:

- Janyn, dors tu?

- Non il, mon signeur.

-Que fais tu doncques?

- Mon signeur, s'il vous plaist, je sounge.

- Reveille toi de par le deable et de par sa mere ov tout. Quey ne m'as tu reveillé bien matin, comme je te comandoi hier soir?

- Mon signeur, par mon serement, si fesoi je.

- Hé, tu mens fausement parmy la gorge. Quelle heure est il maintenant?

- Mon signeur, il n'est que bien matin encore.

- Adoncques ne peut chaloir. Vel sic: Adoncques ne fais compt. Vel sic: Doncques je ne fais force. Vel sic: Il ne m'en chaut doncques. Ore leve toy. Vel sic: Ore levez sus tost. Vel sic: Ore sourdez vous le cul tost et appareillés a diner. (p. 43, 11. 7-20)

- Janyn, are you sleeping?

- Not at all, my lord.

-What are you doing then?

5 It is difficult to gauge the tone of the (friendly?) insults taught in the 1399 Manière, but if we imagine that they were current in the early fifteenth century, as I am inclined to, then the translations 'low, worthless fellow' (for ribaud) and 'rascal' or 'rogue' (for pailard) will not do (compare $A N D 1$, s.vv. ribaud, paillart). Godefroy writes that ribaud is a 'terme d'injure dont la signification est très étendue et très variée' (DAL, s.v. ribaut); it apparently derives from the Old High German verb rîban 'rub', and quickly assumed a sexual valence in Old and Middle French (compare FEW, s.v. rîban). 'Fucker' seems an appropriate Present Day English translation for this term, which insults those to whom it is applied with reference to their supposed involvement in illicit sexual behaviour. The case of pailard is trickier: the word was used to designate stable-workers and those who slept on straw; by extension it could function as an insult directed at the materially less fortunate. Like ribaud, moreover, pailard was also an insult applied to those thought to be engaged in unsanctioned sexual behaviours (compare DMF, s.v. paillard). My translation 'scumbag' is an attempt to match the snobbery and concern for sexual morality that the term pailard apparently communicated; I am grateful to friends who have suggested alternatives: 'scrubber' (UK), 'knacker' (Ireland), 'skeeze' (US). 
- My lord, if it pleases you, I'm thinking.

- Wake up, by the devil and by his mother and the whole pack! Why didn't you wake me up early in the morning as I ordered you last night?

- My lord, on my oath, I did.

- Oh! You're lying through and through. What time is it now?

- My lord, it's still only early in the morning.

- Then it doesn't matter. Or thus: Then I don't mind. Or thus: Then I won't make anything of it. Or thus: It doesn't matter, then. Now get up. Or thus: Now get up right now. Or thus: Now get up off your arse and make breakfast.

It is typical of the more developed Manières dialogues that alongside basic but perfectly serviceable expressions such as the lord's 'Quelle heure est il maintenant?' we find more sophisticated uses of French. Janyn's 's'il vous plaist, je sounge' is simple enough in itself, but the valet's deadpan humour indicates a thoughtful use of language. The gradual shift from tired acceptance to renewed irritation in the alternative lines allotted to the lord likewise suggests an interest in the comic potential of French: the flow of the dialogue can be interrupted not only in order to extend the student's vocabulary, as it is in the first conversation cited from the 1399 Manière ('Dieu vous doint bon jour et bon estraine. $\mathrm{Ou}$ : . . . bon santé $\mathrm{Ou}$ : . . . bon joie'); the pedagogic gesture can in itself provide the matter for a joke. Indeed, the stacking up of the lord's alternative lines might be taken to indicate a delight in the collection of current expressions almost for their own sake.

The Manières are deeply invested in demonstrating the pleasures of learning and speaking French. As my final opening example I cite another dialogue from the 1396 Manière in which learners are invited to imagine the ultimate thrill of being complimented on their language skills by a native speaker (dialogue 21). In this conversation, an Englishman greets a French traveller who has come to England via Venice. Upon learning that the tourist is a Parisian, the Englishman demonstrates his eagerness to practise his conversation skills, all the while waxing lyrical upon the beauties of French:

- Vous parlez bien et graciousement doulx franceys, et pur ce il me fait grant bien et esbatement au coer de parler ovesque vous de vostre beal langage, quar est le plus gracious parler que soit en monde et de toutz gentz meulx preisés et amee que nulle autre. (p. 32, 1l. 26-29)

- You speak excellent French, well and graciously, and so it does me much good and joy at heart to speak with you about your beautiful language, for it is the most gracious language in the world and the best esteemed and loved of all people, excepting none other.

The Englishman continues, expressing in rather florid French his wish that he might speak as well as his interlocutor: 'Hé, plust a Dieu et a la virgyne Marie, mon tresdoulx amy, que je sceusse si bien et graciousement parler franceys com vous savez, quar veraiment j'en fuisse donques bien aisee au coer' (p. 33, 


\section{Practising French Conversation in Fifteenth-Century England}

11. 1-4: 'Oh, that it might please God and the Virgin Mary, my most dear friend, that I might be able to speak French as well and as graciously as you can, for truly I would then be much pleased at heart'). The Frenchman finally replies with the statement of approbation that has perhaps been sought from the outset of the exchange:

- Par Nostre Dame de Clery, je voudroy que vous sceussez, mais toutzvois vous parlez bien assez, ce m'est avys, qar je pense bien que vous avez demurré grant piece la, depuis que vous parlez si bien et plainement la langage. (p. 33, 1l. 5-8)

- By Our Lady of Clery, I wish that you might be able to, but in any case you speak well enough, as I see it, for I think that you have spent a long time there, since you speak the language so well and so expansively.

The Englishman proudly replies that he has never been to France and that he has learnt everything he knows through conversation with 'lez gentz de ce pays icy' (p. 33, 1l. 11-12: 'the people of this country here'). On the one hand this dialogue is clearly an advertisement for the effectiveness of the Manières and the teachers who use them. Like the list of insults in the 1399 Manière, however, this exchange also suggests the currency of a desire among Englishspeakers to become proficient in variously sophisticated forms of current, conversational French, even while they remained in England. If the Manières were to serve their users effectively, the proficiency modelled by the English Francophile in the 1396 dialogue must have been plausibly within reach. Thus, as Ardis Butterfield points out, these conversation manuals complicate traditional narratives of the decline of French usage in early fifteenth-century England: the highly idiomatic nature of the various conversations they contain argues in favour of the continued vitality of the language and a desire to acquire more of it, at least in the milieux where the Manières were taught and studied. ${ }^{6}$

Consideration of the Manières manuscripts suggests that French conversation was practised at a variety of locations throughout England during the late Middle Ages. The early text of the 1396 Manière preserved in London, British Library MS Harley 3988, contains a closing dedication stating that it was 'Escript a Bury Saint Esmon' (p. 45, l. 31: 'written at Bury St Edmunds'); Kristol's discovery of a fragment of the 1399 Manière in a Lincoln formulary suggests

\footnotetext{
${ }^{6}$ See The Familiar Enemy: Chaucer, Language, and Nation in the Hundred Years War (Oxford: Oxford University Press, 2009), p. 335. Kristol also stresses the success with which the Manières reproduce a lively, spoken idiom (see Andres Max Kristol, "'Que dea! Mettes le chapron, paillard, com tu parles a prodome!": la représentation de l'oralité dans les Manières de langage $\mathrm{du} \mathrm{XIV}^{\mathrm{e}} / \mathrm{xv}^{\mathrm{e}}$ siècle', Romanistisches Jahrbuch, 43 (1992), 35-64). For the traditional view that the number of Anglicisms in the 1396 Manière alongside the use of several unusual forms and the incorrect use of gender 'emphasize the decline in the knowledge of French in England at this time', see Wendy Ayres-Bennett, A History of the French Language through Texts (London: Routledge, 1996), p. 137.
} 
that the work was used in that town; ${ }^{7}$ and the versions of the 1415 Manière preserved in Oxford, Bodleian Library MS Lat. misc. e. 93, and Cambridge, University Library MS Dd. 12. 23, contain adapted dialogues that situate their action in London. ${ }^{8} \mathrm{M}$. Domenica Legge's account of the peripatetic career of the cleric and notary John Stevenes, an early owner, and possibly the compiler, of Oxford, All Souls MS 182, suggests at least one way in which these works might have travelled: the All Souls manuscript is an important collection of French teaching texts, including versions of the 1396 and 1399 Manières, and it looks likely to have been put together over several years, perhaps during Stevenes's travels between Canterbury, Exeter, Norwich, Lincoln, London, and Normandy. ${ }^{9}$ But it is with Oxford that the Manières can be most closely associated. It is here that the earlier versions of the 1415 Manière set their dialogues, and this conversation manual can confidently be located within that town because its fifth dialogue contains an advertisement for the Oxford school of the fifteenth-century scrivener William Kingsmill ( $f l$. 1420-50). In this conversation, a knight is asked by a woman to take her twelve-year-old son with him to London and to secure him an apprenticeship there. Calling the boy before him, the knight begins a round of questioning:

- Moun fiz, avez vous esté a l'escole?

- Oy, syre, par vostre congé.

-A quel lieu?

- Syr, a l'ostelle de Will Kyngesmylle Escriven. ${ }^{10}$

- Beau fyz, comben de temps avez vous demurrez ovesque luy?

- Sire, forsque un quart de l'an.

- Cella n'est que un poi temps, mes qu'avez vous apriz la en ycel terme?

- Syr, moun maystre m'ad enseigné pur escrire, enditer, acompter et fraunceys parler.

- Et que savez vous en fraunceys dire?

- Sir, je say moun noun et moun corps bien descriere. (p. 76, 1. 24-p. 77, 1. 1)

- My son, have you been to school?

- Yes, sir, by your leave.

-In what place?

- Sir, at the hostel of the scrivener, William Kingsmill.

- Good son, how long have you stayed with him?

- Sir, only a quarter of a year.

7 See 'Un nouveau fragment de manière de langage: Lincoln, Linc. Arc. Off., Formulary 23', Vox Romanica, 49-50 (1990-91), 311-41.

${ }^{8}$ On these adaptations see Manières, ed. by Kristol, p. xli. Business education, which probably always included an element of French instruction, was taught at a variety of locations throughout medieval England. See further Nicholas Orme, Medieval Schools from Roman Britain to Renaissance England (New Haven: Yale University Press, 2006), pp. 68-73.

9 See Anglo-Norman Letters and Petitions from All Souls MS. 182, ed. by M. Domenica Legge, Anglo-Norman Texts, 3 (Oxford: Anglo-Norman Text Society, 1941), pp. ix-xxi.

${ }_{10}$ Kristol reports the reading of his base text in Cambridge, Trinity College MS B. 14 39/40. Of the three remaining copies of the 1415 Manière, one refers to the school master as 'W. K.'; the other two call him 'Gilliam Scrivener' (see Manières, ed. by Kristol, p. xl). 


\section{Practising French Conversation in Fifteenth-Century England}

- That's only a little while, but what have you learnt there in that time?

- Sir, my master has taught me to write, compose, cast accounts, and speak French.

- And what can you say in French?

- Sir, I can say my name and describe my body in detail.

The boy gives his name as Johan boun enfant and then goes on to list a great deal of vocabulary treating the parts of the body and other topics, sometimes in verse, sometimes in prose. Kristol notes that much of what appears here is culled from Walter de Bibbesworth's popular Tretiz, a thirteenth-century guide to French vocabulary that clearly continued to occupy a central position in language-teaching curricula throughout the late medieval period. ${ }^{11}$

Thanks to the pioneering work of Legge and H. G. Richardson, William Kingsmill and his activities at Oxford can be described in some detail. ${ }^{12} \mathrm{He}$ was one of the previously mentioned Oxford dictatores who specialized in the instruction of letter-writing, or dictamen, alongside the skills necessary to conduct basic business and legal transactions and the French frequently required in order to perform these functions. The 1396 and the $1399 \mathrm{Ma}$ nières ask to be examined in an Oxonian context alongside the 1415 Manière because they are almost invariably compiled in manuscripts alongside other teaching materials that can be linked either to Kingsmill or to his Oxford predecessor, Thomas Sampson ( $f l$. 1350-1409). ${ }^{13}$ Although the Manières were known outside Oxford and might have originated elsewhere, it would seem that Oxford's dictatores exerted an influence on French teaching that extended throughout England: the texts that they wrote and/or used were transmitted in tandem and adapted for instruction at a variety of locations. The particular importance of French instruction in late medieval Oxford speaks in favour of this hypothesis.

Oxford is the only medieval university known to have made official arrangements for the teaching of French. In 1432 the university issued a statute according to which students who had been 'competently instructed only in

${ }^{11}$ Manières, ed. by Kristol, pp. 96-97. An electronic edition of the Tretiz, ed. by William Rothwell, is hosted at <www.anglo-norman.net>.

${ }^{12}$ See Legge, 'William of Kingsmill: A Fifteenth-Century Teacher of French in Oxford', in Studies in French Language and Mediaeval Literature Presented to Professor Mildred K. Pope (Manchester: Manchester University Press, 1939), pp. 241-46, and Richardson, 'Letters of the Oxford dictatores', in Formularies Which Bear on the History of Oxford c. 1204-1420, ed. by H. E. Salter, W. A. Pantin, and H. G. Richardson, Oxford Historical Society, New Series, 5 (Oxford: Clarendon Press, 1942), pp. 329-450 (pp. 339-41). The dates of Kingsmill's period of activity given above are taken from Martin Camargo, 'If You Can't Join Them, Beat Them; or, When Grammar Met Business Writing (in Fifteenth-Century Oxford)', in Letter-Writing Manuals and Instruction from Antiquity to the Present: Historical and Bibliographic Studies, ed. by Carol Poster and Linda C. Mitchell (Columbia: University of South Carolina Press, 2007), pp. 67-87 (p. 72).

13 Compare the list of Manières manuscripts in Manières, ed. by Kristol, p. xi, and the relevant manuscript entries in Dean and Boulton, Anglo-Norman Literature. On Sampson see H. G. Richardson, 'Business Training in Medieval Oxford', American Historical Review, 46 (1941), 259-80. 
grammar' and who were primarily engaged in learning 'the art of writing, composing and speaking in French, the drafting of charters and similar documents, the holding of lay courts, or how to plead in English' should henceforth also be required to attend the university's ordinary lectures in grammar and rhetoric; their masters were to be 'licensed by the chancellor and proctors, sworn to observe the discipline and statutes of the university and placed under the rule of the supervisors of the grammar schools' ${ }^{14}$ It is clear that the statute aims to regulate current teaching practices: Richardson notes that Sampson was already resident in Oxford in 1380 and dates the introduction of French teaching in the town to the early fourteenth century. ${ }^{15}$ Perhaps the university was worried that its students were being poached: the 1432 statute went on to decree that the classes of the dictatores should not clash with the ordinary lectures in the arts faculty. ${ }^{16}$ Certainly, the stipulation that students of dictamen should be made to follow these lectures indicates that, as a rule, the clientele of the dictatores did not typically pursue a regular course at the university. Instead, the dictatores appear to have offered shorter, professionalizing courses in basic business skills to students of a variety of ages and backgrounds: Jehan boun enfant is twelve and spends only four months at Kingsmill's school before his mother thinks him fit to be sent off to be apprenticed; other fictional representations of dictamen students also suggest that short periods of schooling were normal. Richardson edits a model letter contained in one of Sampson's formularies in which a father writes to his son instructing him to give up his studies at the arts faculty and to commit himself to Sampson's teaching: the father has managed to secure his son a job in aristocratic service to begin the following year, and the son should now prepare himself for his new position by learning to 'escrire et diter' and 'bien et visement acompter, escrire et rendre come appent' ('write and compose, and cast accounts well and prudently, and write and make a fitting render'). ${ }^{17}$ Another letter in Richardson's anthology describes the plight of a man who has been appointed to a clerical position above his abilities: he writes to his brother asking him to put himself to learning writing, accounting, and composition so that he can come to his aid, presumably some time in the near future. $^{18}$

${ }^{14}$ Cited from the translation and paraphrase in T. A. R. Evans, 'The Number, Origins and Careers of Scholars', in The History of the University of Oxford, ed. by Trevor H. Aston, 8 vols (Oxford: Clarendon Press, 1984-200o), II: Late Medieval Oxford, ed. by J. I. Catto and Ralph Evans (1992), 485-538 (pp. 525-26). For the Latin text of the statute see Statuta antiqua Universitatis Oxoniensis, ed. by Strickland Gibson (Oxford: Clarendon Press, 1931), pp. 240-41.

15 See Richardson, 'Letters of the Oxford dictatores', pp. 336, 344.

16 On the potential for antagonism between the university and the dictatores, see further Camargo, 'If You Can't Join Them, Beat Them'.

17 'Letters of the Oxford dictatores', p. 407.

18 Ibid., pp. 371-72. 


\section{Practising French Conversation in Fifteenth-Century England}

T. A. R. Evans asserts that the Oxford business teachers 'prepared their pupils for work as clerks at a very modest level' and that the mixture of accounting, letter-writing, and basic legal skills taught 'suggests a training suitable for a local jobbing clerk who might combine work for manorial officers with miscellaneous tasks for other local clients, conceivably in conjunction with some non-clerical occupation'. ${ }^{19}$ Work in this line for competent writers of French does not appear to have been lacking around the turn of the fifteenth century. Richard Britnell has ascertained that demand throughout England for writers capable of composing petitions, proclamations, legal texts, and customaries in the language peaked in the years $1350-1415 .{ }^{20}$ The need for documents written in specialized forms of French helps to explain the production of a new wave of French teaching materials about the turn of the fifteenth century, including Thomas Coyfurelly's Tractatus ortographie Gallicane, ${ }^{21}$ and three grammars: the Donait françois commissioned by John Barton, ${ }^{22}$ the Donait soloum douce franceis de Paris transcribed by Richard Dove, ${ }^{23}$ and the anonymous Liber Donati. ${ }^{24}$ But the incorporation of French conversation into the Oxford business syllabi about this time suggests that some modification of Evans's account of the intended destinations of the students of the dictatores is in order. If the unique goal of the courses of the dictatores was to produce students capable of composing specialized French texts, why was time invested in teaching the forms of the spoken language? Indeed, spoken French would appear to have been practised not only via the Manières but also in classes that used the other new teaching materials just mentioned. Coyfurelly's Tractus elucidates the relationship between French spelling and pronunciation, for instance, and the prefatory comments that Barton appends to his Donait indicate that all four of the key language skills were targeted in this work:

Pour ceo que les bones gens du roiaume d'Engleterre sont enbrasez a sçavoir lire et escrire, entendre et parler droit françois, a fin qu'ils puissent entrecomuner bonement

19 'The Number, Origins and Careers of Scholars', p. 526.

${ }^{20}$ See 'Uses of French Language in Medieval English Towns', in Language and Culture in Medieval Britain: The French of England, c. 1100-c. 1500, ed. by Jocelyn Wogan-Browne and others (Woodbridge: York Medieval Press, 2009), pp. 81-89 (p. 89).

${ }^{21}$ Edited in Edmund Stengel, 'Die ältesten Anleitungsschriften zur Erlernung der französischen Sprache', Zeitschrift für neufranzösische Sprache und Literatur, 1 (1879), 1-40 (pp. 16-24).

${ }^{22}$ Edited in Thomas Städtler, $Z u$ den Anfängen der französischen Grammatiksprache: Textausgaben und Wortschatzstudien, Beihefte zur Zeitschrift für romanische Philologie, 223 (Tübingen: Niemeyer, 1988), pp. 128-37.

${ }^{23}$ Edited in Brian Merrilees, 'Donatus and the Teaching of French in Medieval England', in Anglo-Norman Anniversary Essays, ed. by Ian Short, Anglo-Norman Text Society, Occasional Publications Series, 2 (London: Anglo-Norman Text Society, 1993), pp. 273-91 (pp. 285-91).

${ }^{24}$ Liber Donati: A Fifteenth-Century Manual of French, ed. by Brian Merrilees and Beata Sitarz-Fitzpatrick, Anglo-Norman Text Society, Plain Texts Series, 9 (London: Anglo-Norman Text Society, 1993). 
ové lour voisins, c'est a dire les bones gens du roiaume de France [. . .] j'ey baillé aus avant diz Anglois un Donait françois pur les briefment entreduyr en la droit language du Paris et de païs la d'entour, la quelle language en Engliterre on appelle 'doulce France'. ${ }^{25}$

Because the good people of the kingdom of England are keen to know how to read and write, understand and speak correct French, so that they can communicate properly with their neighbours, that is to say, the good people of the kingdom of France, I have given to the aforementioned English a French Donatus in order briefly to introduce them to the correct language of Paris and the surrounding country, which language is called in England 'sweet French'.

More crucially, if the need for these specialized French texts declined 'quite rapidly' after 1415 , as Britnell has it, ${ }^{26}$ why did spoken and written French continue to constitute an important aspect of the business curricula taught at Oxford and elsewhere throughout the first half of the fifteenth century? Of course, it might be objected that the teaching offered by business schools typically lags behind developments in the workplaces for which they would prepare their students. But the financial survival of the dictatores and their colleagues throughout the country depended on their ability to attract private students, and students and their parents continued to want their professionalizing brand of education at least into the middle decades of the fifteenth century. It thus seems reasonable to assume that these teachers remained alert to the needs of their clients and tailored their courses accordingly.

While many medieval business students no doubt went on to pursue the local, jobbing clerical work that Evans and Britnell discuss, the Manières also contain dialogues which suggest that at least some of these learners harboured different ambitions, abroad rather than at home. The heyday of the Manières corresponded with some of the most spectacular English successes in the Hundred Years War. ${ }^{27}$ Henry V's first invasion of France in 1415 led to the capturing of the Norman port of Harfleur and culminated in his magnificent

${ }^{25}$ Cited from Städtler, Zu den Anfängen der französischen Grammatiksprache, p. 128.

${ }^{26}$ Britnell, 'Uses of French Language in Medieval English Towns', p. 89.

${ }^{27} \mathrm{My}$ attempt to situate the Manières within the context of contemporary developments in the Hundred Years War asks readers to suspend their knowledge of the outcome of the conflict in order better to understand the ebb and flow of people and language across the Channel throughout its duration. In so proceeding I have been inspired by the example set by Butterfield in her Familiar Enemy. The coincidence of developments in French education and the prosecution of the Hundred Years War has been examined in different terms by Serge Lusignan, who suggests that the currency of French was maintained in England by royal authority: the English monarchs' claims to be reuniting a kingdom divided by Valois depredations might be reinforced if the inhabitants of that hypothetical kingdom could be shown to speak the same language (Parler vulgairement: les intellectuels et la langue française aux XIII et XIV siècles (Vrin: Presses de l'Université de Montréal, 1986), pp. 107-11). More recent studies have expressed scepticism concerning the interest of the English kings in pursuing language policies of this kind (indeed, in Anglo-Saxon scholarship Edward III and Henry V have been traditionally associated with language policies that promoted English, not French). See, for example, W. M. Ormrod, 'The Use of English: Language, Law, and Political Culture in Fourteenth-Century England', Speculum, 78 (2003), 750-87. As an 


\section{Practising French Conversation in Fifteenth-Century England}

victory against the French army at Agincourt; his second sally into the country would result in further gains: Touques, Caen, and Bayeux fell into English hands in 1417, followed by Cherbourg in 1418 and Rouen at the opening of 1419. By mid-spring in 1419 most of Normandy was in English hands; on 21 May 1420 Charles VI signed the Treaty of Troyes conferring the succession to the French throne upon Henry; and in August 1424 the Duke of Bedford's victory at the Battle of Verneuil secured the existence of an English settlement in the north of France for the next twenty-five years. ${ }^{28}$ These victories presented a range of opportunities for Englishmen willing to travel to the Continent, for the new settlement must be populated if it was to be viable. Alongside soldiers and administrators, English Normandy needed merchants and artisans. Thus, less than a month after the capitulation of Harfleur on 18 September 1415, Bedford, in his capacity of keeper of the realm, issued a writ requiring the sheriffs of London to proclaim that all merchants, victuallers, and artisans who were willing to reside in the town of Harfleur should go there with all speed, and that the captain of the town would provide them with houses. Once settled there, the writ continued, the king would grant them a charter of liberties. ${ }^{29}$ There is subsequently recorded a 'crye made for the comune passage toward Harflieu' in which it is promised that the mayor of London will assign shipping to willing emigrants:

Be there proclamacioun made, that alle manere of men, marchauntz, artificers, or other of what estat, degre, or condicioun, that euere theye be, that willen toward oure lige Lorde the Kyng, beyng atte Harflewe in the costes of Normandye, that God him spede, with corne, brede, mele, or floure, wyne, ale, or biere, fysshe, flesshe, or any other viteille, clothe, lynnen, wollene, or eny merchaundise, sheytys, breches, doublettys, hosene, shone, or eny other manere ware of armure, artilrye, or of othere stuffe; lette him apparaille and make redy betwen this and to day sevenyght their bodyes, goodes, merchaundyses, ware, stoffure, viteilles, what that euer it be; and in the mene while come to the Mair, and he shalle dispose and assigne theym redy shippyng and passage vnto the forseid costes. ${ }^{30}$

As is evident from this last proclamation, English Harfleur needed thingscorn, bread, flour, wine, ale, beer, and so forth-but it also needed people to bring them over. And people came. By the beginning of 1416, for example,

alternative to Lusignan's top-down explanation for the perpetuation of French teaching, this essay seeks to illuminate the motivations that might have prompted individual learners seek out a French education of their own volition.

${ }^{28}$ On the prosecution of the war in Normandy see C. T. Allmand, Lancastrian Normandy 1415-1450: The History of a Medieval Occupation (Oxford: Clarendon Press, 1983), pp. 1-49.

29 The writ was published on 5 October 1415, as noted in Calendar of Letter-Books Preserved among the Archives of the Corporation of the City of London, Letter-Book I, ed. by Reginald R. Sharpe (London: Corporation of the City of London, 1909), p. 159.

30 Cited from Memorials of London and London Life in the 13th, 14th, and 15th Centuries, ed. by Henry T. Riley (London, 1868), p. 628. The proclamation is undated, but Sharpe assigns it to October 1415 in Letter-Book I, p. 161. 
English masons and carpenters had arrived to repair the town, which had suffered under a six-week siege before capitulating to the English, and artisans such as these would appear to have been among the first to have benefited from the numerous property grants given at Harfleur and Caen during the occupation: 497 such grants are known for Harfleur; 178 survive for Caen. ${ }^{31}$

The international context in which students practised French conversation at Oxford and elsewhere in the early fifteenth century cannot have been far from learners' thoughts: the 1415 Manière even contains a dialogue in which a traveller coming from France gives a detailed account of the French defeats at Harfleur and Agincourt (dialogue 2). It is clear that the French student who had mastered the material presented in the Manières would have been particularly well placed to make the most of the opportunities presented by the English territorial gains in Normandy. ${ }^{32}$ Alongside the basic day-to-day French required in order to frame a greeting and ask the way, the $1396 \mathrm{Ma}$ nière sets out model conversations, showing, for example, how an apprentice might secure a leave of absence when he is injured (dialogue 6), how he might get the best price for his master's wares at market (dialogue 7 ), or how a qualified craftsman might find a new position (dialogue 22). This last conversation might perhaps best be read as an advertisement for the easy availability of temporary employment on the Continent:

- Moun tresdoulx sir, Dieu vous avance.

- Bien soiez venuz, beau sir.

- Ou demure le meillour cousturer de ceste ville?

- Purquoy demandez vous, mon amy?

- Pur ce que je voerey avoir un bon maistere pur overer ovesque lui.

- Estez vous cousturer donques?

- Oil, veraiment, sir.

- Vuillez vous overer ovesque moy?

- Oil, sir, tresvoluntrés, se vous me vuillez doner atant come nulle autre.

- Que vous donorai je la semaigne?

- Sir, vous me donrrez set souldz deux deners et mes despensez.

- Quantbien de tens pensez vous d'arester en ce ville?

-Dymy ans, s'il Dieu plest. (p. 34, 11. 20-34)

${ }^{31}$ See Anne Curry, 'Henry V's Harfleur: A Study in Military Administration, 1415-1422', in The Hundred Years War, ed. by L. J. Andrew Villalon and others, 3 vols (Leiden: Brill, 2005-13), III: Further Considerations, ed. by L. J. Andrew Villalon and Donald J. Kagay (2013), 259-84 (pp. 272, 278-79).

32 The coincidence of the reproduction and use of the Manières with the Lancastrian invasion and occupation of Normandy, and in particular the Agincourt report in the 1415 Manière, invite consideration of the applications of the Manières's lessons to life in the new English territory. It should be pointed out, however, that the Manières would also have benefited learners travelling along different axes, either to Aquitaine, an older English possession on the Continent, or to the French-speaking Lowlands (to name but two obvious trajectories). It might have been with such destinations in mind that the earliest versions of the Manières were redacted. 


\section{Practising French Conversation in Fifteenth-Century England}

- My dear sir, God help you.

- May you be welcome, good sir.

- Where does the best tailor in this town live?

- Why are you asking, my friend?

- Because I would like to have a good master to work with.

- Are you a tailor, then?

- Yes, sir, truly.

- Would you like to work with me?

- Yes, sir, most willingly, if you will give me as much as any other.

- What shall I give you a week?

- Sir, you will give me seven sous two deniers, and my expenses.

- How long do you intend to stay in this town?

- Half a year, God willing.

Without further ado, the master tailor accepts his interlocutor's terms and invites him to start work for him immediately. What better illustration could there be for the purported usefulness of the business French taught in the Manières?

The 1396 Manière also contains a series of conversations in which a lord has sent his valet on commissions about town (dialogues $4,8,17,18$ ), as well as a dialogue that models a conversation between two working men of lower status entitled 'une manere du parler dez labourers et overurs des mestiers' (p. 17, 1. 3, dialogue 5: 'a way of speaking proper to labourers and craftsmen'). It is unlikely that French would have been used within England in all of these working contexts; on the Continent, however, these kinds of French would have been indispensable for new settlers since the territory that they inhabited continued to be home to a majority of native French-speakers. Indeed, given the prominence of craftsmen, apprentices, and servants among the speaking parts modelled in the Manières, it seems reasonable to assume that students with these backgrounds constituted an important portion of the English French teachers' clientele. Insofar as they are not only about but also for artisans in particular, these conversation manuals would appear to constitute something of a rarity: in her study of artisans and medieval narrative craft, Lisa $\mathrm{H}$. Cooper stresses the paucity of historically reliable representations of skilled manual labourers, their image being most usually deployed in the interests of other social groups. ${ }^{33}$ The Manières thus have the potential to shed new light on the needs, priorities, and attitudes of this large but elusive section of the late medieval workforce.

33 Thus although Cooper sees a development in the representation of artisans in medieval language teaching texts away from 'schematizing craft labor in the abstract to embedding it in a concretely imagined economic and social world', the works which she examines in greatest depth (Ælfric's Colloquy and Caxton's Dialogues in French and English) demonstrate the persistence of attempts to assert other (monastic or mercantile) interests over those of the artisans they depict. See Artisans and Narrative Craft in Late Medieval England (Cambridge: Cambridge University Press, 2011), pp. 19-55 (Cooper addresses the Manières briefly at p. 34). 
Ian Cornelius has written perceptively about the ways in which the guides to letter-writing and the model letters studied in the Oxford business schools and elsewhere inculcate an understanding of the social hierarchy to which the learner belongs; the detailed salutations that became standardized learning matter in the later Middle Ages in particular codified the status of and relations between a letter's sender and recipient. ${ }^{34}$ The Manières would also appear to have prepared their users for particular social roles, both in the administrative and paralegal branches at home and, as I am arguing, in a range of artisanal and mercantile positions on the Continent. A feature common to both the letter manuals and the Manières is, however, that they require learners to study the modes of expression proper to both the superior and the subordinate parties in the exchanges that they model. Alongside a series of often anonymous petitions to the king and his officers, for instance, the letters anthologized in Oxford, All Souls MS 182, also include numerous examples of the epistolary styles of kings Richard II and Henry IV. ${ }^{35}$ Likewise, as we have seen, at the same time as they imagine the future lives of their learners in aristocratic service or as apprentices, the Manières also devote considerable time to describing the lifestyles and exemplifying the speech of their users' future masters. While teaching materials of this kind implicitly ally the acquisition of French with imminent professional success in a series of predetermined positions, then, they also invite their users to consider the extent to which social positions are enacted through the use of particular kinds of language. This lesson must have been particularly clear to the users of the Manières, texts whose dialogic form requires learners to perform both superior and subordinate parts in real-time acts of classroom drama.

The most spectacular lordly performance in the Manières comes at the opening of the 1396 text. After a brief prologue and an account of the vocabulary necessary in order to describe the human body, all the extant versions of this conversation manual contain a scene that describes the furnishing of an empty house (dialogue 3). A lord arrives at a hostel and sends his valet to summon the keeper of his wardrobe, a carpenter, a mercer, and a draper. $\mathrm{He}$ gives his valet long lists of things to order from these men as well as a series of instructions for things he should buy himself:

Auxi que vous m'achatez de chaiers, fourmez, sciellez, tables, aes, un table pur hanaps, brichets, basyns, chaufours, un euar pendaunt.

Et pur le pantrie et botrie que vous achatés du payn non pas chaufenous, mes de bon payne levee, et payn leger auxi beal et blanc com l'en poet trovere en tout le monde, et

${ }^{34}$ See 'The Rhetoric of Advancement: Ars dictaminis, Cursus, and Clerical Careerism in Late Medieval England', New Medieval Literatures, 12 (2010), 289-330.

35 See further the indexes of letters attributed to Henry and Richard in Anglo-Norman Letters and Petitions, ed. by Legge, pp. 486, 491-92. 


\section{Practising French Conversation in Fifteenth-Century England}

quatre tonelx de bon vyn vermaile, trois tonelx de malvesyve, cinque tonelx de blanc et deux tonelx de romney, et ce de meillour que poet estre trové ent tout ce pays ici.

Auxi que vous achatez poz de peautur et d'argent, cuillers d'argent, goblés, piecez d'argent, madrez, terrens, veirres, cuteulx bien tranchantz, chargeours, platez, escuilez, saucers, salers pur seil et chaundlers de fin argent. (p. 5, 1l. 9-19)

Also buy me chairs, benches, stools, tables, planks, a table for goblets, trestles, basins, saucepans, a hanging bucket.

And for the pantry and buttery, buy bread-not mouldy bread but good, risen bread, and light bread as good and as white as can be found in all the world-and four casks of good red wine, three casks of sweet wine, five casks of white and two casks of romney, and that of the best that can be found in all this country here.

Also buy pewter and silver pots, silver spoons, goblets, silverware, wooden cups, earthenware pots, glasses, sharp knives, bowls, plates, cups, saucers, salt cellars for salt and fine silver candlesticks.

The lists continue, and on the one hand the narrative framing of this episode clearly serves as a pretext for a rehearsal of the vocabulary of household objects. At the same time, the rubric introducing the dialogue announces that it will reveal the key to lordly life: 'Ore je vous divisaray lez chocez necessaries a homme' (p. 4, 1. 17: 'Now I will describe for you the things necessary to a man'). As he calls out for these various things, the student performing this portion of the 1396 Manière practises not only the French names of lordly appurtenances, he also learns the way in which aristocratic identity constructs itself through the calling up of things, and he learns the breathless, demanding tones in which such objects are to be summoned into his presence.

Where they afford their users an opportunity to play the lord, the Manières foreshadow the early Tudor collections of vulgaria analysed by Paul Sullivan: Sullivan demonstrates that the variety of personae staged in these short texts written to be translated between English and Latin afforded pupils an opportunity to ventriloquize, among other characters, 'prosperous burghers, and imperious men of parts'; he goes on to argue that the vulgaria thus presented 'an array of borrowed experiences full of genuine possibility for self-fashioning', and that their performance in oral examinations fostered an understanding of social roles as playing parts. ${ }^{36}$ It should now be clear that the early fifteenth-century Manières support a comparable dramatic pedagogy, but one that is activated through the instruction of practical French rather than increasingly academic Latin, through classroom dialogue rather than through translation, and in the context provided not by the endowed grammar schools whose workings Sullivan illuminates but by the more pro-

${ }^{36}$ See 'Playing the Lord: Tudor Vulgaria and the Rehearsal of Ambition', English Literary History, 75 (2008), 179-96 (pp. 180, 182). For a recent anthology of vulgaria and an introduction to their classroom applications, see English School Exercises, 1420-1530, ed. by Nicholas Orme, Studies and Texts, 181 (Toronto: Pontifical Institute of Mediaeval Studies, 2013). 
visional business schools that grew up around the Oxford dictatores and their colleagues throughout England. Under these conditions, it remains uncertain to what extent Sullivan's optimism regarding the socially transformative potential of Tudor education might be transferred to an interpretation of the earlier texts. Undoubtedly, a few of the ambitious Englishmen who went to France were successful. One Nicholas Bradkyrk, for example, a merchantdraper, probably from London, arrived in Normandy c. 1420; by 1424 he was a receiver of taxes at Caen and in 1428 he was promoted in that office; by January 1436 he had become vicomte of Bayeux, and in August 1443, as an esquire, he was styled lord of Fourmengney in the bailliage of Caen. ${ }^{37}$ Predictably, though, Bradkyrk's case is an isolated one, ${ }^{38}$ and, perhaps inevitably, his education history remains obscure.

The fundamental issue here is whether the experience of playing the lord at school could have fostered among users of the Manières the self-confidence that they might one day take his place. I find this unlikely. Quite apart from the real obstacles to upward social mobility in late medieval Europe, the users of the Manieres must also have been aware of the limitations of their instruction, despite the self-promotional tactics that we have observed in action in the 1396 and 1415 Manieres. The practice of the conversations contained in the Manières must have been accompanied by an awareness that a virtuoso performance in an English classroom would be harder to pull off before an audience of native French-speakers. Indeed, the very idea that social identities might be reconstituted through performance is the source of much of the humour in a prose fabiliau told in four of the extant versions of the 1396 Manière (dialogue 4.7). The fabliau, which has an analogue in the seventh novella of the seventh day of the Decameron, tells the story of a woman in Burgundy who tricks her husband into a false impression of his squire's moral impeachability as a prelude to accepting the squire as her lover. The nocturnal climax of the narrative sees the husband dressed in his wife's clothes, waiting to tempt and then entrap the squire in his courtyard. The squire has been warned, however, and has received instructions from the wife to beat the husband and to assail him with a series of invectives, treating the husband as if he really were the wife: 'Va t'en a ton lit, maveise putaigne que tu es,' he is told to say, 'va t'en de par deable et de par sa mere ové tout, ou autrement je toi rumperai le colle devant que tu bougeras deci' (p. 15, 11. 17-19: 'Go back to your bed, evil whore that you are. Get lost by the devil and his mother and the whole pack, or otherwise I'll break your neck before you budge from here'). The comedy in the story is many-layered, but a large part of it derives from the credulousness of the husband, who believes that the squire will be tricked

37 See Allmand, Lancastrian Normandy, p. 90.

${ }^{8}$ Allmand proposes that the lack of records for named English merchants at Caen demonstrates that they 'made but little mark upon the town' (ibid., p. 101). 


\section{Practising French Conversation in Fifteenth-Century England}

into thinking that he is his wife and who does not recognize that the squire's moralizing attack is an act. If social roles are theatrical parts, as the Manières seem to suggest, then the fabliau indicates that social actors are in fact highly specialized creatures who are often fit to play only one role: only a fool such as the husband in this tale can be deceived into thinking that the performance of an alternative identity might be commensurate with reality.

Rather than viewing the Manières as motors of social change, then, it might make most sense to interpret them as registers of a curiosity and a cautious optimism regarding the potential for upward social mobility. This optimism marks a number of Middle English text genres, in particular conduct books. In a late fifteenth-century version of John Lydgate's Stans puer ad mensam, for example, the child addressee is promised that courtesy is a fail-safe key to success, regardless of background: 'The child that is curtas, be he pore or ryche, | It schall hym avayll' (ll. 17-18). ${ }^{39}$ The same text presents manhood not as a biological fact but as a role that must be learnt and performed according to 'this scryptour', i.e. the written advice that is about to be delivered:

Therfor this scryptour, my sone, if thou rede,

And thinke in thiselve that thou wold be a man, Unto syche poyntes I rede thou take hede,

As thou schall hereafter rede if thou canne.

(11. $28-31)$

But where Stans puer ad mensam and similar conduct texts argue that a mixture of self-restraint and polite deference to one's superiors is the surest way to prosperity, the Manières adumbrate an alternative route to riches via a daring self-displacement to the Continent and the mastery of one's master's speech. Although historical research demonstrates that optimism of this kind rarely bore lasting fruit, $4^{\circ}$ the forms in which it comes still have much to tell us. It is never one-sided and, if we listen carefully, it can often be heard to contain its antithesis. Reading between the lines of the Manières-or the vulgaria, for that matter-means not only uncovering a readiness to play the lord; it also involves registering the things that their users worried about: losing their job in a foreign country because of an injury, not finding a job at all, not finding the inn. As C. T. Allmand points out, the success of a settlement such as that in Normandy depended not on those who went there with the ambition of making it big but on the people of more humble designs 'who came to live in Normandy and to lead out their lives there' and who looked upon

39 The poem is cited by line number from Codex Ashmole 61: A Compilation of Popular Middle English Verse, ed. by George Shuffelton (Kalamazoo: Medieval Institute Publications, 2008), pp. 60-67.

${ }^{40}$ See e.g. Philippa C. Maddern, 'Social Mobility', in A Social History of England, 1200-1500, ed. by Rosemary Horrox and W. Mark Ormrod (Cambridge: Cambridge University Press, 2006), pp. 113-33. 
the settlement as 'a source of everyday livelihood for themselves and their children' ${ }^{41}$ If we can learn to read them better, the Manières de langage have the potential not only to tell us something about these people's dreams of upward social mobility; they can also afford us access to their anxieties and expectations and to their sense of how they might work these out through dialogue with the people alongside whom they would live during the final years of the large-scale English presence in late medieval France.

UNIVERSITY OF FRIBOURG

Rory G. CRitTen

${ }^{41}$ Lancastrian Normandy, pp. 73, 74. 